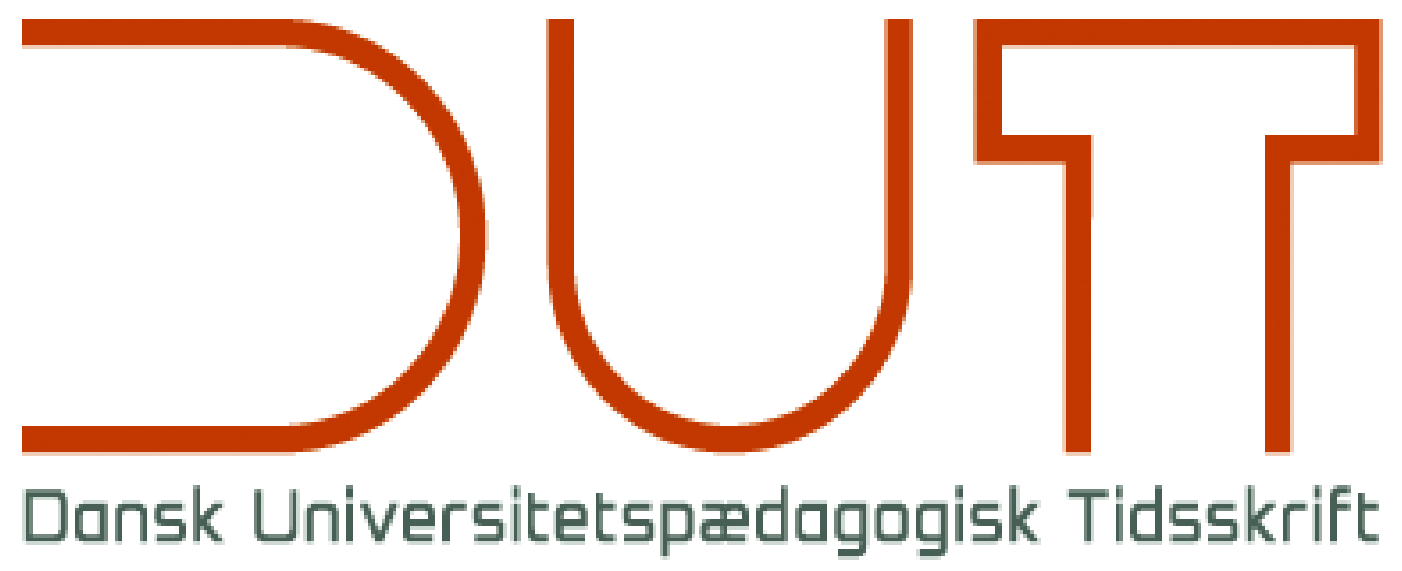

Tema

Undervisningens teknologier og teknikker

Årgang 15 nr. 28 / 2020

Titel

Jagten på den gode opgave: Identifikation af kriterier og implementering af peer feedback i praksis

Forfattere

Sidetal

Laura Mark Jensen, Mette Burmølle, Bjørn Friis Johannsen, Jesper Bruun, Marianne Ellegaard

$16-30$

Udgivet af

Dansk Universitetspædagogisk Netværk, DUN

URL

> http://dun-net.dk/

Betingelser for brug af denne artikel

(c) Copyright
Denne artikel er omfattet af ophavsretsloven, og der må citeres fra den. Følgende betingelser skal dog være opfyldt:

- Citatet skal være i overensstemmelse med "god skik"

- Der må kun citeres „i det omfang, som betinges af formålet“

- Ophavsmanden til teksten skal krediteres, og kilden skal angives ift. ovenstående bibliografiske oplysninger.

DUT og artiklens forfatter 


\title{
Jagten på den gode opgave: Identifikation af kriterier og implementering af peer feedback i praksis
}

\author{
Laura Mark Jensen ${ }^{\mathrm{a}, 1}$, Mette Burmølle ${ }^{\mathrm{b}}$, Bjørn Friis Johannsenc ${ }^{c}$, Jesper Bruund, Marianne Elle- \\ gaard $^{\mathrm{a}}$ \\ ${ }^{a}$ Det Natur-og Biovidenskabelige Fakultet, Københavns Universitet

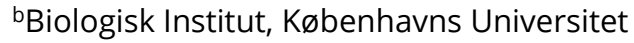 \\ 'Læreruddannelsen Forskning og Udvikling, Københavns Professionshøjskole \\ dInstitut for Naturfagenes Didaktik, Københavns Universitet \\ eHR-Udvikling Københavns Professionshøjskole
}

Faglig artikel, fagfællebedømt

\begin{abstract}
Denne artikel beskriver baggrunden for et pilotprojekt med formativ peer feedback på et karaktergivende essay på et stort obligatorisk bachelorkursus. Peer feedback blev implementeret hovedsageligt som svaret på et behov hos de studerende for mere feedback. Vi diskuterer teorien bag peer feedback som metode i undervisningen og udmøntningen af projektet, inklusive processen bag udformningen af kriterier for peer feedbacken. Gennem interviews med nogle af de involverede studerende og gennem de studerendes spørgsmål i processen fik vi indblik i, hvordan de studerende opfattede peer feedback-processen, hvad der virkede for dem, og hvilke udfordringer der opstod. Efterbehandlingen satte især fokus på det nyttige, for både undervisere og studerende, $i$ at præcisere kriterier for en sådan opgave.
\end{abstract}

\section{Introduktion og teori}

Forskning viser, at inddragelse af studerende i evalueringsprocesser rummer mange værdifulde elementer, der både fremmer de studerendes forståelse af læringsmål og udvikler deres metakognitive og akademiske færdigheder (fx Falchikov, 2005; Tsai, Lin \& Yuan, 2002; Zoller \& Ben-Chaim, 1997). Inddragelsen af studerende i evalueringsprocessen ved hjælp af peer feedback (fx Topping 2009) dannede ramme om et pilotprojekt på kurset Almen Mikrobiologi. Kurset er obligatorisk for ca. 200 studerende på 2. år på biologistudiet på KU, og igennem flere år har de studerende i deres evalueringer af kurset efterspurgt mere feedback. For eksempel skal de studerende i løbet af kurset aflevere en obligatorisk hjemmeopgave, der tæller $1 / 3$ af deres endelige eksamenskarakter (resten af karakteren udgøres af en skriftlig eksamen efter kurset), og de oplever ikke, at de modtager tilfredsstillende feedback på denne opgave. Underviserne oplever på den anden side, at de ikke har tid til at give feedback på så mange individuelle opgaver. De tilbyder de studerende, der ønsker feedback, mundtlig feedback på deres opgaver efter endt karaktergivning, men mange vælger ikke at tage imod denne mulighed, da de allerede er mentalt videre med et andet kursus. Underviserne oplever desuden oftest, at de studerende, som ønsker feedback på deres opgaver, er studerende, der har skrevet en god opgave og gerne vil bekræftes heri, eller studerende, som er utilfredse med deres karakter og derfor gerne vil vide, hvorfor deres opgave muligvis har trukket dem ned. Når studerende har modtaget summativ evaluering, vil de måske gerne have be-

1Kontakt: laura.jensen@sund.ku.dk 
dømmelsen uddybet, men behovet for (og effekten af) formativ evaluering forsvinder (Yorke, 2003). Derfor er det vigtigt, at formativ evaluering går forud for summativ evaluering.

Pilotprojektet, som vi beskriver i denne artikel, havde til formål at afprøve muligheder for at facilitere og støtte studerende $i$ at give hinanden brugbar formativ feedback (herefter benævnt peer feedback).

Opgaven er et kort essay inden for et defineret område af mikrobiologien. Der er 10 forskellige opgaveformuleringer, som fordeles tilfældigt blandt de studerende på kurset. Det er den første skriftlige akademiske opgave, baseret på videnskabelige artikler, som de studerende møder i løbet af deres studie, og særligt finder de det svært at strukturere en sådan opgave. Pilotprojektet havde til hensigt at afprøve peer feedback som metode for at imødekomme ønsket om feedback på opgaven, at hjælpe de studerende igennem opgaven ved at formulere tydelige kriterier for, hvordan den ville blive evalueret, samt at inspirere til, hvordan en akademisk opgave kan struktureres. Forskning viser tydeligt, at det at indlejre evaluering som en del af undervisningen både forbedrer undervisningen, fremskynder de studerendes læringsproces og ikke mindst giver de studerende både værktøjer til og mulighed for at udvikle egen læring (Vlachou, 2015). Men skal de studerende inddrages i en formativ evalueringsproces, er det vigtigt, at de studerende kan tage ejerskab over læringsmålene samt kriterier for bedømmelse, således at de har et solidt grundlag for at vurdere sig selv og hinanden. En del af dette forudsætter underviserens tydelige og gennemskuelige kommunikation (Harlen, 2007), ligesom dialog mellem undervisere og de studerende er nødvendig (Rienecker \& Bruun, 2012 og referencer deri). I tråd med dette er det vigtigt at etablere et refleksions- og beslutningsrum, dvs. rammerne for de "strukturerede procedurer og fora, hvor evalueringsresultaterne drøftes, og der træffes beslutninger om, hvilke konsekvenser der skal drages heraf" (Christensen, 2006, s. 365). Formålet med refleksionsrummet er at give den lærende mulighed og rum til at vurdere sine egne kompetencer ud fra den modtagne feedback, mens formålet med beslutningsrummet er at bruge disse refleksioner til at ændre sine handlinger fremadrettet. Et eksempel på en formalisering af refleksions- og beslutningsrum er en tabel, $\mathrm{i}$ hvilken underviseren skriver sin feedback i en kolonne, den studerende sine refleksioner i en anden kolonne og senere, i en tredje kolonne, hvilke beslutninger der er taget i forbindelse med at omsætte feedbacken. Arket fungerer som en løbende oversigt over feedback, refleksioner og handling (Ellegaard et al., 2018).

Underviseren har en central rolle som vejleder i evalueringsprocesserne (Falchikov, 2005). Det kommer for eksempel til udtryk i, hvordan kriterierne for evalueringsprocessen formuleres. Vi valgte at formulere kriterierne som en rubric (se fx Reddy \& Andrade, 2010) via læringsplatformen Canvas. En rubric er en guide, der beskriver de specifikke kriterier for bedømmelse af opgaven. En rubric indeholder ofte både beskrivelser af de enkelte kriterier og en niveaudeling inden for det enkelte kriterium; for nogle forfattere er niveaudeling en essentiel del af en rubric, og de kan være beskrevet med ord som skal gøre det nemmere for bedømmeren at bedømme opgaven (Reddy \& Andrade, 2010; Panadero \& Jonsson, 2013). Et kriterium kan for eksempel være, at en opgave perspektiverer teori til praksis. Rubricen kan så give beskrivelser af forskellige niveauer, hvorpå dette gøres, og det vil være op til bedømmeren at vurdere, hvilket niveau en given opgave ligger på. Dawson (2017) viser, hvordan rubrics har (mindst) 14 forskellige anvendelsesmuligheder, blandt andet som understøttelse i peer feedback. Rubrics kan benyttes til at danne rammerne for både peer feedback, selvevaluering og evalueringskriterier ved at specificere de kriterier, opgaven bliver bedømt på. Brug af rubrics kan afhjælpe de studerendes præstationsangst og øge deres self-efficacy og evne 
til selvregulering ved at gøre bedømmelsesprocessen mere gennemsigtig og feedbacken mere tydelig. Rubrics kan således bidrage til at skabe det refleksionsrum, Christensen (2006) omtaler, og samtidig fungere som retningslinjer for de studerendes feedback til hinanden (Reddy \& Andrade, 2010). Vores fokus har været på at fremme formative aspekter af de studerendes feedback, og da niveaudeling kan opfattes summativt, valgte vi ikke at inkludere disse i vores rubric-design, som minder om det, som nogle forfattere kalder single point rubric (se bl.a. Fluckiger 2010).

Peer feedback kan være et vigtigt alternativ til feedback fra underviseren, da både det at give og modtage feedback kan fremme de studerendes læring (Nicol, Thomson \& Breslin, 2014). Feedback er derfor ikke alene et greb, som underviseren kan benytte sig af for at indfri læringsmålene mest effektivt. Det kan også anvendes til at inddrage de studerende aktivt og engagere dem i læringsmålene (Harlen, 2007, og se fx William og Leahy, 2015 for en praktisk indføring i formativ undervisning). Derved bliver peer feedback et værktøj, som kan hjælpe studerende med at udvikle sig til reflekterede og kritiske individer (Falchikov, 2005). Dette kan ske uden nødvendigvis at højne underviserens arbejdsbyrde (Nicol, Thomson \& Breslin, 2014). Denne sidste pointe er vigtig, idet underviserne på dette, og andre kurser, ikke har kapacitet til at give skriftlig feedback på alle opgaverne grundet det høje antal studerende.

At bruge peer feedback i formativt øjemed kan have en række fordele. Den feedback, som studerende giver, er ofte formuleret i et sprog, som er mere tilgængeligt for andre studerende (Black et al., 2004). En anden fordel er, at de studerende, der giver feedback, ofte sætter sig i en rolle "as authors, to different reader's perpectives" (Cho \& Cho, 2011), en rolle, der er særligt vigtig i udviklingen af skrivefærdigheder. I modsætning til forestillinger om autoritetens betydning for læring argumenterer Black et al. (2004) for, at feedback fra en medstuderende oftest bliver taget mere seriøst, end hvis det kom fra underviseren, og at studerende har nemmere ved at acceptere kritik fra en medstuderende end fra en underviser. Dette sætter for eksempel Brown, Peterson \& Yao (2016) spørgsmålstegn ved ud fra en betragtning om, at studerende ofte efterlyser underviserfeedback i tilgift til peer feedback med den begrundelse, at de har svært ved at vurdere, om deres medstuderendes feedback er valid. I tråd med dette fandt Brown et al. (2009) ud af, at studerende opfattede peer feedback som 'meget rart', men ikke som relateret til læring. Dette problem kan imødekommes ved træning og stilladsering af de studerende, som begge er vigtige elementer i situationer, hvor studerende skal involveres i en peer feedback-aktivitet (Panadero, Jonsson \& Striibos, 2016).

Der kan også være andre problematikker forbundet med at anvende peer feedback. For eksempel kan et krav om peer feedback udløse stress og angst i forbindelse med processen, da nogle studerende føler større pres, fordi de selv i højere grad skal levere, og tidsstyre, mere (McDowell, 1995). Nogle studerende kan opleve, at det er ubehageligt dels at se et stykke arbejde, der er bedre end deres eget, dels at andre studerende skal se deres arbejde, da peer feedback-processer ikke altid kan anonymiseres (Purchase, 2000). De samme følelser kan desuden komme til udtryk, hvis en studerende føler tidspres og oplever dårlig introduktion til peer feedback eller manglende træning $i$ at anvende og modtage det. Et andet problem er, at der er forskel på, hvor dygtige (eller flittige) studerende er til at give feedback til hinanden, og nogle studerende kan derfor føle, at de har gjort mere ud af det end andre (Mathews, 1994).

Endelig er det vigtigt at inddrage de studerende i evalueringsprocessen ved at give dem en form for ejerskab, medansvar og -indflydelse. Motivation er et begreb, som endnu ikke er 
entydigt defineret (Damberg, 2006). Det optræder ofte i en undervisningsmæssig sammenhæng, hvor man skelner mellem indre og ydre motivationselementer. Et indre motivationselement sættes ofte i forbindelse med individets personlige udvikling, mens et ydre motivationselement ofte skal ses i sammenhæng med personens omgivelser. Et indre motivationselement bør ses fra et kognitivt perspektiv, hvor der udvikles viden, forståelse og refleksion. Lysten til at holde fast i sine mål, opnå selvudfoldelse og selvtillid kan ligeledes ses som indre motivationselementer. Det er altså værdier, der kommer indefra, og stræben efter at opnå en indre belønning. Den ydre motivationsfaktor, er derimod skabt gennem omgivelserne. Her kan der være tale om belønning og straf, som for eksempel en karakter. Her skelnes mellem positive og negative forstærkninger. Den positive forstærkning kan være en konstruktiv eller rosende kommentar på en opgave, som individet har ejerskab på. Denne form for belønning kan medføre øget motivation, idet det føles anerkendende. Den negative forstærkning, derimod, kan hæmme motivationen, og et eksempel på en negativ forstærkning kan være en ubegrundet, dårlig karakter.

I pilotprojektet, som denne artikel omhandler, kunne studerende anvende peer feedback til at forbedre deres opgave inden den endelige aflevering ud fra kriterier, som stemte overens med undervisernes. En forudsætning for at gennemføre et pilotprojekt om peer feedback var, at undervisernes kriterier blev gjort eksplicitte. Den næste del af artiklen beskriver dette arbejde, herunder hvordan de studerende blev inddraget i peer feedback-processen, derefter følger en evaluering af pilotprojektet, og artiklen afsluttes med en diskussion og overvejelser af muligheder for videreudvikling.

\section{Pilotprojektet}

Jagten på 'den gode opgave' - at gøre implicitte kriterier eksplicitte

Selv om undervisere som regel ikke er i tvivl, om hvornår de læser en god opgave, er det ofte ikke eksplicit, hvad der præcist definerer den gode opgave. En given opgave kan desuden af forskellige bedømmere opnå forskellige vurderinger og karakterer (Harlen, 2005). Udfærdigelsen af rubrics med udgangspunkt i, hvad underviserne lægger vægt på, kan dog bidrage til at danne konsensus om, hvad der evalueres (Dawson, 2017).

Som forberedelse til udformningen af evalueringskriterierne blev 27 tidligere rettede, kommenterede og pointsatte eksamensopgaver analyseret med det formål at afsøge kriterier for, hvad hver enkelt retteansvarlig underviser opfatter og fremhæver som tegn på en god opgave. Undervisernes kommentarer blev nedskrevet, og herefter blev alle opgaver læst i lyset af disse kommentarer. For opgaver med højt pointtal, blev der sat en streg ud for den relevante kommentar, hver gang den var afspejlet i teksten. Var opgavens fokus, for eksempel, præsenteret i starten, blev der sat en streg ud for kommentaren 'Opgaven indeholder præsentation af fokus', mens der for opgaverne med lavt pointtal i stedet blev noteret, hvilke elementer der manglede. På denne måde kunne man sammenligne indholdet af opgaver med henholdsvis højt og lavt pointtal.

Derudover blev de relevante dele af kursets læringsmål inddraget, og der blev desuden foretaget et interview med den kursusansvarlige for at belyse hendes billede af undervisernes forventninger til de studerendes obligatoriske opgaver. Interview, som metode, skal først og fremmest forsøge at åbne op for informantens synspunkter og forestillinger om opgaven. Interviewet blev sat op fem dage før kursusstart, og foregik på den kursusansvarliges kontor. Forud for interviewet var kursusbeskrivelsen læst samt de ovenstående 27 bedømte eksa- 
mensopgaver læst og analyseret. Formålet med interviewet var at få italesat, hvilke læringsog kompetencemål, der danner rammerne for bedømmelsen af opgaverne hos underviserstaben.

Ofte når man skal udføre et interview, er informanten en person, som man ikke kender. I denne situation var der på forhånd opbygget et bekendtskab med den kursusansvarlige, og hun var, allerede inden interviewet, informeret om, hvad der søgtes. Derfor besluttedes det ikke at indvie kursuslederen i resultatet af analysen af opgavebedømmelser samt læringsmål identificeret i kursusbeskrivelsen, da dette måske ville farve hendes opfattelse af, hvilke lærings- og kompetencemål opgaven indeholder for hende. Således kunne interviewet med kursuslederen benyttes som en anden, uafhængig kilde til at sikre en formulering af evalueringskriterier med høj kvalitet. Som et tredje led i formuleringen af kriterier benyttedes et tidligere udformet retteark for opgaverne.

Inden den endelige udformning af kriterierne blev de retteansvarlige undervisere inviteret til at stemme om, hvor vigtigt de fandt hvert af de læringsmål, der var identificeret undervejs. På den måde blev alle underviserne inkluderet i den endelige beslutning om, hvilke elementer der er vigtige i en retteproces. De dele, der fik mange stemmer, blev overskrifter for de overordnede kriterier, mens elementer, som fik få stemmer, blev inkluderet i form af stikord (Tabel 1). De elementer, der ingen stemmer fik, blev ikke inkluderet.

I formuleringen af kriterierne blev der med vilje udelukkende valgt interrogative pronominer til at påbegynde sætningen for at forhindre de studerende i at svare udelukkende 'ja' eller 'nej' på evalueringskriterierne. Åbne spørgsmål tvinger den studerende til at besvare spørgsmålet med et mere velovervejet svar end lukkede spørgsmål. Endvidere tillader de åbne spørgsmål fortolkning af opgaveformuleringerne (Hancock, 1995), hvilket også var vigtigt for den kursusansvarlige. Åbne spørgsmål har nemlig den funktion, at de tilbyder den studerende at nærme sig et problem på mere end én måde, og de resulterer derfor ofte $\mathrm{i}$ mere komplekse og refleksive svar end lukkede. De åbne spørgsmål indeholder altså elementer, som kan fremme progression for de studerende i forhold til Blooms taksonomi.

Da resultatet af kriterieanalysen introduceredes for de studerende i forbindelse med at de skulle give hinanden feedback, blev det tydeliggjort, at både kriterier og stikord er vejledende og ikke en endegyldig opskrift på den perfekte opgave. De blev bedt om kun at bruge eller udfylde de kriterier, de fandt relevante for den opgave, de gav feedback på. Ud over de fem generelle kriterier blev der for hver af de ti opgaveformuleringer formuleret to opgavespecifikke kriterier; samt givet mulighed for at markere eller bruge andre relevante kriterier (som "Andet"). 


\begin{tabular}{|c|c|c|}
\hline Tema & Kriterier & Stikord \\
\hline Formalia & $\begin{array}{l}\text { Hvordan er kravene } \\
\text { om formalia opfyldt? }\end{array}$ & $\begin{array}{l}\text { (Stikord: Antal anslag? Er referencelisten konsekvent? } \\
\text { Er kravet om antal referencer opfyldt? Er kildehenvis- } \\
\text { ningen konsekvent? Er der anført eksamensnummer og } \\
\text { opgavenummer? Er der tekst og kilde på eventuelle } \\
\text { billeder og figurer? Er de videnskabelige navne anført i } \\
\text { kursiv?) }\end{array}$ \\
\hline $\begin{array}{l}\text { Layout og over- } \\
\text { skuelighed }\end{array}$ & $\begin{array}{l}\text { Hvordan oplever du } \\
\text { opgavens layout og } \\
\text { opbygning? }\end{array}$ & $\begin{array}{l}\text { (Stikord:Virker layoutet overskueligt? Er opgaven af- } \\
\text { snitsopdelt? Er der en logisk sammenhæng fra start til } \\
\text { slut?) }\end{array}$ \\
\hline \multirow[t]{2}{*}{ Indhold } & $\begin{array}{l}\text { Hvordan lykkedes det } \\
\text { indholdet i opgaven at } \\
\text { præsentere opgavens } \\
\text { fokus samt at holde } \\
\text { fokus? }\end{array}$ & $\begin{array}{l}\text { (Stikord: Er fokus relevant for opgaveformuleringen? } \\
\text { Er mikrobiologi i fokus, eller er andre discipliner som } \\
\text { kemi, biokemi, historie, økonomi m.m. overskyggende? } \\
\text { Er det de mikrobiologiske detaljer, der dominerer? Er } \\
\text { der en indledning til stede, som sætter scenen med en } \\
\text { præsentation af emnet? Er det tydeligt, hvor vi befinder } \\
\text { os i dette forskningsfelt? Er det tydeligt, hvad opgaven } \\
\text { har for mål? Er der argumentation for fokus og målet? } \\
\text { Er der en god konkluderende afslutning, hvor hoved- } \\
\text { punkterne bliver opsummeret? Demonstreres der (for- } \\
\text { holdsvis) bred viden indenfor emnet?) }\end{array}$ \\
\hline & $\begin{array}{l}\text { Hvordan bliver de } \\
\text { udvalgte cases an- } \\
\text { vendt? }\end{array}$ & $\begin{array}{l}\text { (Stikord: Er der fokus på én eller få cases? Bliver de } \\
\text { væsentlige hovedpunkter trukket ud af de anvendte } \\
\text { cases? Refereres der til specifikke forsøg via en artikel } \\
\text { eller review? Anvendes litteraturen til at understøtte } \\
\text { udsagn?) }\end{array}$ \\
\hline Litteratur & $\begin{array}{l}\text { Hvordan vurderer du } \\
\text { den indsamlede litte- } \\
\text { raturs relevans, tro- } \\
\text { værdighed og brug- } \\
\text { barhed? }\end{array}$ & $\begin{array}{l}\text { (Stikord: Er litteraturen relevant? Er det primært litte- } \\
\text { ratur af nyere dato? Virker noget af litteraturen over- } \\
\text { flødig? Opfylder den kravene om review og artikler, } \\
\text { eller er der primært brugt lærebøger eller hjemmesi- } \\
\text { der?) }\end{array}$ \\
\hline Sprog & $\begin{array}{l}\text { Hvordan er opgavens } \\
\text { sprog? }\end{array}$ & $\begin{array}{l}\text { (Stikord: Formår opgaven at formidle indholdet ud fra } \\
\text { et objektivt synspunkt? Er formuleringerne forståelige } \\
\text { og præcise? Er opgaven velargumenterende for på- } \\
\text { stande? Er opgaven både refererende og senere pro- } \\
\text { blematiserende eller diskuterende? Er det uden genta- } \\
\text { gelser? Er niveauet tilpasset modtageren? Er brugen af } \\
\text { fagtermer anvendt fornuftigt, eller virker de påklistre- } \\
\text { de?) }\end{array}$ \\
\hline Andet & $\begin{array}{l}\text { Hvis du har andre } \\
\text { kommentarer til opga- } \\
\text { ven, kan du indsætte } \\
\text { dem her. }\end{array}$ & \\
\hline
\end{tabular}

Tabel 1. Der blev i alt identificeret fem overordnede, brede temaer for de generelle kriterier. 1) Formalia, 2) Layout og overskuelighed, 3) Indhold, 4) Litteratur og 5) Sprog. Disse fem te- 
maer blev udformet til syv generelle kriterier (hvoraf et hed 'andet' og tillod fritekst). Dertil kom de stikordssætninger, som vejledende inkluderer relaterede kriterieelementer, mhp. at uddybe og eksemplificere de fem generelle kriterier.

Inddragelse af de studerende - What's in it for me?

Deltagermotivationen, der, som beskrevet i teoriafsnittet, er essentiel for at optimere processen (Christensen, 2006), kobles ofte sammen med inddragelsen i evalueringen samt udbyttet heraf. Det er derfor vigtigt, at det er tydeligt og gennemskueligt for den studerende, hvad de personlige fordele ved at deltage er. I dette tilfælde i særlig grad, fordi deltagelse i et pilotprojekt, der ikke var indlejret som et egentligt kursuselement, var frivillig. I præsentationen af projektet til de studerende blev de ovenstående motivationskategorier overvejet. Særligt blev spørgsmålet om social motivation, som handler om etableringen af rollemodeller, som man kan identificere sig med og lade sig inspirere af, brugt i selve præsentationssituationen. Fordi pilotprojektet var del af et bachelorprojekt, blev hele processen introduceret af en bachelorstuderende, der selv havde taget kurset. På den måde blev det forsøgt at etablere et kammeratligt miljø, kendetegnet ved gensidighed. Særligt var det intentionen, at de studerendes engagement skulle drives af, at de kunne se deres eget bidrag til andres arbejde som et gensidigt forhold, der i sidste ende ville komme ligeligt tilbage: Man hjælper hinanden og på den måde også sig selv.

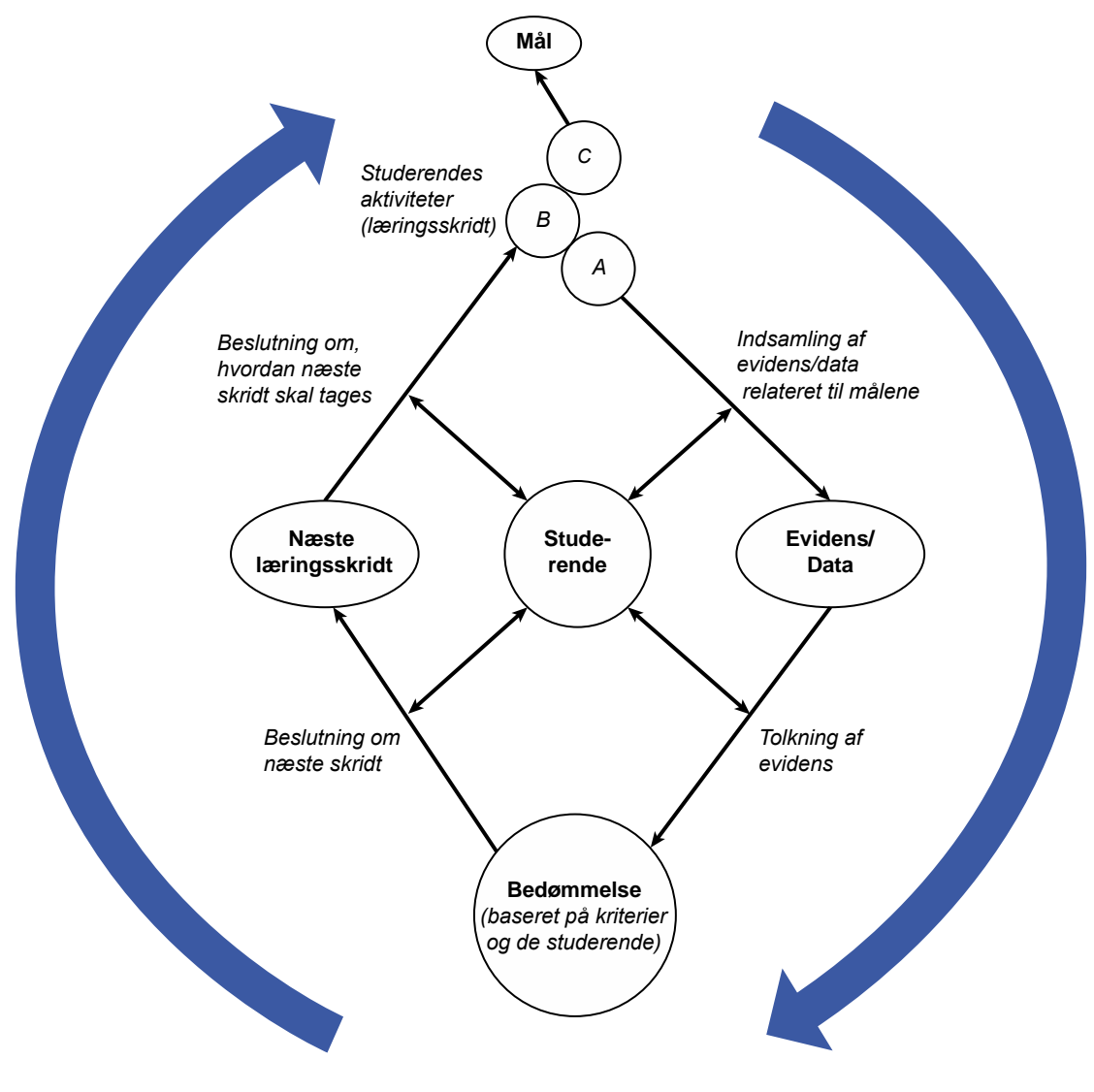

Peer feedback

Figur 1. Modificering af Wynne Harlens (2006) feedbackmodel. Modellen beskriver, hvordan en studerendes løsning af en opgave (A) informerer eller 'føder tilbage' til lærings-arbejdet omkring en relateret opgave (B) $i$ et cirkulært, formativt forløb. Under aktiviteten A bruges 
den lærendes aktivitet eller løsning af A som evidens, der tolkes og bedømmes i forhold til læringsmålene. Herefter vurderes og tilpasses tolkningen af evidensen, således at den anvendes til at identificere et næste læringsskridt og give progression i den studerendes arbejde på måder, der også forholder sig til læringsmålene. Der er her tale om en illustration af en procestænkning snarere end om et forløb i tid.

\section{Feedbackforløbet}

Forløbet bestod af fire trin. Det første trin bestod i at introducere de studerende til projektet. Dette gav de studerende mulighed for både at stille spørgsmål til projektet samt møde den ansvarlige for processen. Her blev de informeret om, at deltagelse i forsøget var på frivillig basis, og at man først behøvede at tage stilling til, om man ønskede at deltage, den dag, der var deadline for upload til peer feedback. Som en del af oplægget blev de studerende introduceret til Wynne Harlens model for formativ evaluering (se Figur 1), som havde til formål at illustrere det til tider komplekse tankemønster, der er en del af den formative tænkning, der ønskes hos de studerende. Modellen beskriver den formative evaluering som et cirkulært forløb, hvor der under aktiviteten A indsamles evidens, som i dette tilfælde vil være identificering, i den medstuderendes rapport, af tekst, som svarer på de kriterier, som er beskrevet i tabel 1. De studerende vil derefter skulle evaluere, hvordan den medstuderende opfylder læringsmålene som angivet gennem kriterierne (Harlen, 2006).

Herefter vurderes og tilpasses fortolkningen af evidensen, således at den anvendes til at skabe progression i forhold til læringsmålene. Det essentielle og relevante i denne model er, at der er tale om en tankeproces og ikke et forløb i tid. Der er altså ikke nødvendigvis tale om en fysisk undervisningstime eller om bevidste valg, underviseren foretager, men snarere om en tankeproces, som bør aktiveres, når man ønsker at hjælpe en medstuderende videre fra et sted til et andet ved for eksempel at give feedback på en opgave.

Den svære del for de studerende er at mestre den del, hvor man på en formativ manér skal formulere, hvordan modtageren kan forbedre sin besvarelse af opgaven. Her blev det tydeliggjort, at man skulle forsøge at tænke sig selv i modtagerens sted og gøre sig tanker om, hvilken type 'råd' man selv ville værdsætte og ville kunne 'bruge til noget'. Denne del af forløbet blev stilladseret ved et kort handout med eksempler på, hvordan feedback kan formuleres konstruktivt, præcist og formativt, samt ved at tilbyde en workshop, hvor de studerende kunne komme og diskutere deres forslag til feedback. Det blev desuden understreget, at det forventedes, at man anvendte to timer på selve feedback-processen, hvilket studerende efterfølgende bekræftede var tilstrækkeligt. En anden ting, der blev lagt vægt på, var muligheden for fortolkning af både kriterier og opgaveformuleringerne. Det blev bl.a. understreget, at der er mange gode måder at løse den samme opgave på, hvilket også spejles i, at der ikke blev angivet niveauer i rubricen.

Det andet trin bestod $\mathrm{i}$, at de studerende ved et åbent hus-arrangement kunne stille spørgsmål til forsøget med peer feedback. Det tredje trin var dagen, hvor feedbacken skulle gives. Til formålet blev der oprettet ti 'opgaverum' på portalen, hvori man skulle uploade i det 'rum', der svarede til ens opgavenummer. På baggrund af teorien om, at jo mere feedback, man modtager, des større er muligheden for, at man modtager feedback, man kan anvende konstruktivt (Cho \& MacArthur, 2010), blev det besluttet, at hver deltager fik uddelt to opgaver, som de skulle give feedback på. Der blev til dette formål afholdt en feedback-workshop, hvor deltagerne kunne komme forbi og få vejledning i både den administrative del og $i$ at give feedback. Yderligere fik de tilbud om vejledning online via mail. Dette trin skabte en unik 
mulighed for at observere de studerendes tilgang til at give peer feedback, samt hvordan de i praksis forstod at manøvrere rundt i de forskellige kriterier, de skulle forholde sig til. Endvidere åbnede muligheden sig for at forhøre nogle af de studerende, som ikke deltog i forsøget, om hvorfor de havde valgt ikke at deltage. Det fjerde og sidste trin var perioden, efter de studerende havde modtaget deres feedback. Feedback-processen var planlagt således, at de studerende, som havde været med i feedback-processen, havde to dage til at gennemlæse den feedback, de havde modtaget, og anvende de dele af den, som de fandt nyttige og relevante at arbejde videre med. Det var muligt for de studerende at få hjælp til at anvende og implementere den modtagne feedback via mail eller ved at planlægge et fysisk møde. Denne periode bød både på tilfredse og frustrerede studerende, som oplevede det at få feedback på vidt forskellige måder. Under hele forløbet, blev underviserne informeret om processen.

I alt valgte 24 studerende at deltage i projektet, hvoraf alle både gav og modtog feedback. Dette udgør $12,7 \%$ af deltagerne på kurset. Derudover havde alle studerende adgang til alle kriterier via platformen, uanset om de valgte at deltage eller ej.

\section{Evaluering}

Som et vigtigt led i evalueringen af pilotprojektet blev løbende mailkorrespondancer med de deltagende studerende brugt til at afkode, hvordan de oplevede at være med i hele feedback-processen. Desuden interviewedes to studerende, som havde valgt at bruge muligheden for peer feedback, og én, som havde fravalgt muligheden.

I korrespondancerne kan man se, at enkelte studerende oplevede frustrationer over ikke at modtage feedback:

Jeg har desvaerre ikke fået noget feedback tilbage. Så mit spørgsmål går på om hvad jeg så gør! Er ret frustreret, da jeg har brugt lang tid på at rette men af mine medstuderendes opgave... eller er jeg bare for tidligt på den?

Jeg deltager i feedback-projektet på kurset i Almen Mikrobiologi. Det ser ud som om, at jeg allerede har fået min opgave/feedback tilbage. Men! Måske kan jeg bare ikke se den rigtige feedback endnu, og ellers har jeg bare voret rigtig uheldig med den person, der skulle rette. Det eneste jeg har modtaget er nemlig en kommentar, hvor der står Pisse godt skrevetskal ikke kunne sige om det kunne gøres bedre. Hvordan finder jeg den egentlige feedback?

I den første situation viste det sig, at problemet kunne løses, idet der var tale om et administrativt problem. I det andet tilfælde havde hun ikke fået andet feedback end det, der stod nævnt i hendes kommentar. De studerende var på forhånd blevet informeret om, at man kunne risikere at modtage feedback, som var 'ubrugelig'.

Interview af de studerende

Efter at de studerende, der valgte at deltage i projektet, havde uploadet deres besvarelse, modtaget feedback, behandlet og vurderet deres feedback og endelig afleveret deres endelige besvarelser til vurdering, blev tre studerende inviteret til at deltage i et interview om processen.

Det første interview blev planlagt som et fokusgruppeinterview med det formål at få flere synspunkter præsenteret (Kvale \& Brinkmann, 2009) i et ikke-styrende interview, idet grup- 
pesamspillet kan reducere interviewerens kontrol. Interviewet med den studerende, der ikke deltog, blev dog udført som et enmandsinterview.

Hvad synes de studerende?

Fokus blev lagt på to temaer: De studerendes oplevelse af at se andres arbejde, samt hvordan deltagerne fandt kriterierne for evalueringen.

[..]det er fedt og lige at se nogle andres opgaver og se deres perspektiv på det. Så kan man $i$ hvert fald, selv om man måske ik' vil aendre noget $i$ sin egen, så har man alligevel lige toenkt over, om man burde gøre det.

[..] det var rart at se de andres opgaver og have nogle spørgsmål at forholde sig til med sin egen opgave. Jeg synes faktisk, at det hjalp mest, at man så de spørgsmål, du havde stillet, og så loeste den andens opgave, for det feedback jeg brugte, brugte jeg faktisk ikke til soerlig meget.

Som det ses i ovenstående kommentarer, gav de studerende udtryk for, at de fandt specielt det at se hinandens opgaver og tilstedeværelsen af stikord anvendeligt i processen. I relation hertil skrev en studerende i en mail, at hun syntes, at det, der var mest givende for hende, var, at hun ved at læse andres opgaver blev drevet ud i refleksion over sin egen opgave, hvilket andre studerende, som har været involveret i peer feedback, også tidligere har udtalt (Nicol, Thomson \& Breslin, 2014). På den måde har feedback-processen og anvendelsen af kriterierne fungeret, $\mathrm{i}$ hvert fald for disse studerende, som et refleksionsrum (som beskrevet $\mathrm{i}$ introduktionen).

Kriterierne har generelt været brugbare i processen - ikke mindst til eget brug, også for studerende, som ikke deltog i peer feedback-processen. En af de studerende nævner i interviewet, at der meget gerne måtte have været flere stikord. Den studerende, der ikke deltog i processen, downloadede endda kriterierne til eget brug og anvendte de punkter, han fandt relevante, som en slags 'tjekliste' for, hvad han skulle fokusere på - noget flere gav udtryk for at have gjort. Denne observation er også tidligere gjort (Nicol, Thomson \& Breslin, 2014).

En studerende nævner dog, at hun ikke brød sig om at anvende rubricen, idet hun ikke kunne lide at give feedback på baggrund af faste rammer.

[..] nogen gange kan jeg godt have svoert ved at følge sådan en opskrift. Altså så kigger jeg, [..] lidt på det, og så svarer (jeg) på dem. Så var det lettere bare at skrive ind i teksten: 'det her sårn og sårn..' og uploade det.

Flere studerende gav desuden udtryk for, at de fandt kriteriet om at vurdere den medstuderendes udvalgte referencer svært, idet de fandt det tidskrævende og på for højt niveau at tage stilling til. Generelt oplevede de studerende selve feedback-processen som givende, men drog ikke nødvendigvis nytte af den feedback, de modtog. Tiden så ud til at være en afgørende faktor for, at flere studerende ikke deltog i processen, og én ville have ønsket, at hendes opgave var mere færdig, da hun uploadede den til feedback. Den studerende, der ikke deltog, begrundede desuden sin manglende deltagelse i peer feedback-processen med, at han ikke havde et færdigt produkt, som kunne uploades. Flere af de studerende, der deltog helt eller delvist i processen, har desuden givet udtryk for, at de alligevel regner med at opsøge feedback på opgaven hos underviserne i slutningen af kurset. 
Stikordenes betydning for feedbacken og feltet 'andet'

Ser man på, hvordan stikordene har betydning for, hvad de studerende fokuserer på i feedbacken, kan man tage udgangspunkt i nedenstående (Figur 2 og 3):

\begin{tabular}{|l|l|}
\hline Kriterie & Rating \\
\hline Formalia & Referencelisten mangler nogle \\
dele. Der skal stå sidetal og jour- \\
nal på artikler. Første kilde mang- \\
ler, men det er du nok opmoerk- \\
som på. Jeg ville vaelge at bruge tal \\
og ikke romerske tal, det virker lidt \\
forvirrende, men det er nok en \\
smagssag. \\
\\
Det virker til, at alt står $i$ kursiv, \\
hvor det skal, men tjek alligevel \\
igennem en ekstra gang.
\end{tabular}

Figur 2. Første eksempel på feedback, som har fokus på stikordene

\begin{tabular}{|l|l|}
\hline Kriterie & Rating \\
\hline Layout og opbygning & $\begin{array}{l}\text { Det er fint opdelt i afsnit, kig lige } \\
\text { på stavningen, der er nogle fejl, og } \\
\text { layoutmoessigt ville det hjoelpe, } \\
\text { hvis du brugte automatisk ordde- } \\
\text { ling :-) Men bortset fra det er lay- } \\
\text { outet rigtig fint! Sammenhoeng ja, } \\
\text { men prøv at koble lidt mere af, der } \\
\text { du redegør for i første afsnit, til } \\
\text { din diskussion! :-) }\end{array}$ \\
\hline
\end{tabular}

Figur 3. Andet eksempel på feedback, som har fokus på stikordene

Dette stemmer overens med, hvad de studerende i ovenstående afsnit udtalte om anvendelsen af kriterierne. Flere af dem refererede til dem som en slags 'tjekliste' og ønskede endda, at der havde været flere 'spørgsmål'. Dette gør, at feedback bliver af en summativ karakter, idet der bliver svaret med ja/nej-tilgange. Denne tilgang kan tænkes at skyldes stikordene, idet de studerende måske ignorerer det overordnede kriterie.

Selv om mange valgte ikke at udfylde feltet 'andet', har enkelte dog knyttet kommentarer hertil. En af dem ses i det nedenstående eksempel (Figur 4): 


\begin{tabular}{|l|l|}
\hline Kriterie & Rating \\
\hline $\begin{array}{l}\text { Hvis du har andre kommenterer } \\
\text { til opgaven, kan du indsætte } \\
\text { dem her. }\end{array}$ & $\begin{array}{l}\text { Fint pakket opgave, men jeg føler, } \\
\text { at den er lidt overfladisk, så det } \\
\text { ville vare godt at have noget mere } \\
\text { teori og eventuelt nogle figurer. }\end{array}$ \\
\hline
\end{tabular}

Figur 4. Eksempel på feedback, som åbner op for et nyt kriterie for opgaven

Den studerende har i dette tilfælde selv identificeret et kriterium, som han synes er vigtigt for opgaven. Han nævner ordet 'overfladisk', som ikke er et element, der bliver omtalt nogen steder i rubric'en. Man kan, som en interessant del i identificeringen af kriterier for en evalueringsproces, inddrage de studerende. Denne feedback, som de studerende har givet til hinanden, kan derfor anvendes som feedback til den eller de undervisere, der er ansvarlige for formuleringen af kriterierne. De kan her vælge at se på, om kriterierne bør indeholde flere eller færre stikord, eller om de helt bør fjernes for måske at fremprovokere en mere formativ feedback, hvor man kommer væk fra en summativ 'tjekliste'-struktur. Endvidere kan man som underviser overveje, i hvilken grad man bør inddrage de studerende i formulering af kriterierne.

\section{Diskussion}

Denne artikel har til hensigt at vise, hvordan peer feedback kan implementeres i forsøget på at imødekomme efterspørgslen på feedback fra de studerende.

\section{Kriterier}

Vores arbejde med at formulere kriterier illustrerede, hvor nyttig denne proces, og resultatet af den, kan være for både studerende og undervisere. Det har endda vist sig, at det er denne del af pilotprojektet, som i første omgang er blevet implementeret som en fast del af kurset. Således blev det i projektet synliggjort, at de studerende savnede klare retningslinjer for opgavens opbygning og indhold. De udarbejdede generelle kriterier er derfor efterfølgende blevet lettere modificeret og udleveres nu, når opgavetitlerne offentliggøres. Forløbet tydeliggjorde ligeså det store udbytte af at få lov at læse eksempler på gode opgaver; dette formodes især at skyldes, at det er den første "akademiske opgave" (dvs. baseret på primærlitteratur), de studerende skriver. Derfor bliver gode, tidligere opgaver nu gjort tilgængelige for de studerende i skriveprocessen. Det er undervisernes klare indtryk, at disse tiltag bidrager til større ro og sikkerhed hos de studerende, hvilket afspejles i reduceret frustration og færre henvendelser til underviserne i skriveperioden. Der var således tegn på, at feedbackkriterierne og processen omkring peer feedback-pilotprojektet førte til en bedre forståelse hos de studerende af, hvordan denne opgave ønskedes struktureret. Desuden har processen på lidt længere sigt ført til ændret kommunikation om opgaven.

\section{Peer feedback-processen}

Vi anser det for en succes at hele 12,7\% valgte at deltage. Muligheden for at deltage i processen var frivilligt for de studerende, og man kan derfor argumentere for, at forsøget på at mo- 
tivere kursisterne til at deltage må have haft en effekt. De studerende oplever mange krav til deres tid, og signalet om, at ordningen var frivillig (og et pilotforsøg), kan have ført til, at den ikke blev prioriteret. Med hensyn til målet om øget feedback så kunne alle, der ville, deltage og derved få feedback; dog oplevede nogle få studerende at den feedback, de fik, ikke var brugbar. Underviserne på kurset har indtil videre valgt ikke at gøre ordningen permanent, men med basis i den generelt positive feedback fra deltagerne opfordres de studerende til selv at etablere lignende ordninger internt. Disse vil naturligvis mangle elementer som for eksempel anonymitet, men kan dog stadig stimulere læring forbundet med at læse andres opgaver.

Det er muligt, at en kulturændring er nødvendig, før man med større succes kan etablere peer feedback på et kursus. For både undervisere og studerende er peer feedback en evalueringsform, som kun bliver anvendt på meget få kurser. De er derfor ikke bekendte med begrebet. Var peer feedback en mere etableret evalueringsform på flere kurser, ville man måske se en højere deltagerprocent og feedback af en mere formativ karakter.

I vores forsøg på at etablere peer feedback så vi, hvordan de studerende var tilbøjelige til at anvende stikordene som 'tjekliste', hvilket måske har resulteret i en mere summativ end formativ tilgang til feedbacken. Vi ønskede at etablere en formativ evalueringspraksis, som der blev arbejdet hen imod, bl.a. ved hjælp af handouts om formativ feedback og ved at bruge en rubric uden niveaudeling. En grundigere og mere omfattende analyse af den feedback, de studerende gav til hinanden, kunne måske svare på, om dele af feedbacken faktisk var formativ. En sådan analyse ville også kræve inddragelse af de studerende, der modtog feedbacken, for at undersøge, hvordan den blev anvendt rent praktisk, og på det grundlag justere kriterierne. Det var ikke muligt at lave en systematisk evaluering af effekten af peer feedbackprocessen på de studerendes læring; det var dog undervisernes subjektive vurdering, at kvaliteten af essays var høj dette år.

\section{Udfordringer og videreudvikling}

Pilotprojektet viste, at vil man implementere peer feedback på et kursus, skal man være forberedt på at håndtere situationer, hvor de studerende oplever at få feedback, de ikke kan bruge, fra en medstuderende. I interviewene kom det også frem, at tidspres kan føre til, at ordningen ikke fungerer optimalt, hvilket stemmer overens med McDowells (1995) observation om, at den studerende kan føle ubehag ved peer feedback, når han føler tidspres. I dette tilfælde kunne det være som følge af den logistiske struktur, hvor peer feedback-processen lå tæt på deadline for den endelige aflevering af opgaven, og der derfor ikke var meget tid til at arbejde i dybden med feedbacken. Dette ville kunne bearbejdes sammen med de studerende, hvis peer feedback bliver brugt gentagne gange på et kursus eller i løbet af uddannelsen. Ydermere er det vigtigt at afsætte den nødvendige tid til træning og bearbejdelse af feedbacken. En anden måde, man i fremtiden kan inddrage de studerende på, vil være i identificeringen af kriterierne. Dette kunne gøres gennem et tæt samarbejde mellem underviseren og de studerende samt ved en grundigere analyse af den feedback, der blev udvekslet mellem de studerende. 


\section{Litteraturliste}

Black, P.J., Harrison, C., Lee, C., Marshall, B. (2004). Working Inside the Black Box: Assessment for Learning in the Classroom. Phi Delta Kappan 86 (1): 9-21.

Brown, G. T., Irving, S. E., Peterson, E. R. \& Hirschfeld, G. H. (2009). Use of interactive-informal assessment practices: New Zealand secondary students' conceptions of assessment. Learning and Instruction, 19(2), 97-111.

Brown, G. T., Peterson, E. R. \& Yao, E. S. (2016). Student conceptions of feedback: Impact on self-regulation, self-efficacy, and academic achievement. British Journal of Educational Psychology, 86(4), 606-629.

Cho, Y.H. \& Cho, K. (2011). Peer Reviewers Learn from Giving Comments. Instructional Science 39 (5): 629-643.

Cho, K. \& MacArthur, C. (2010). Student Revision with Peer and Expert Reviewing. Learning and Instruction 20 (4): 328-338.

Christensen, T. S. (2006). Formativ evaluering. I Gymnasiepoedagogik, 361-382. København: Reitzels.

Christiansen, F. V., Horst, S. \& Rump, C. (2013). “Kursusbeskrivelser. I Universitetspaedagogik, 133-146. København: Samfundslitteratur.

Damberg, E. (2006). Motivation. I Gymnasiepaedagogik, 206-266. København: Reitzels.

Dawson, P. (2017). Assessment rubrics: towards clearer and more replicable design, research and practice. Assessment \& Evaluation in Higher Education 11: 1-14.

Ellegaard, M. Damsgaard, L., Bruun, J. \& Johannsen, B. F. (2018). Patterns in the form of formative feedback and student response. Assessment \& Evaluation in Higher Education 43, 727-744.

Falchikov, N. (2005). Improving Assessment Through Student Involvement: Practical solutions for aiding learning in higher education and further education. New York: Routledge.

Fluckiger, Jarene, "Single Point Rubric: A Tool for Responsible Student Self-Assessment" (2010).Teacher Education Faculty Publications. 5.

Hancock, Lynn C. 1995. Enhancing mathematics learning with open-ended questions. The Mathematics Teacher 88.6: 496.

Harlen, W. (2005). Trusting teachers' judgement: Research evidence of the reliability and validity of teachers' assessment used for summative purposes. Research papers in education, 20(3), 245-270.

Harlen, W. (2006). On the Relationship Between Assessment for Formative and Summative Purpose. I Assessment for Learning, ed. John Gardner, 87-102. London: Sage.

Harlen, W. (2007). Criteria for evaluating systems for student assessment. Studies in Educational Evaluation 33: 15-28.

Kvale, S. \& Brinkmann, S. (2009). Interview: Introduktion til et haindvoerk. 2. ed. København: Reitzels. 
Mathews, B.P. (1994). Assessing individual contributions: experience of peer evaluation in major group projects. British Journal of Educational Technology 25 (1): 19-28.

McDowell, L. (1995). The Impact of Innovative Assessment on Student Learning. Innovations in Education \& Training International 32 (4):302-213.

Nicol, D., Thomson, A. \& Breslin, C. (2014). Rethinking feedback practices in higher education: a peer review perpective. Assessment in Higher Education 39 (1): 102-122.

Panadero, E.\& Jonsson, A. (2013). The Use of Scoring Rubrics for Formative Assessment Purposes Revisited: A Review. Educational Research Review 9: 129-144.

Panadero, E., Jonsson, A., Strijbos JW. (2016) Scaffolding Self-Regulated Learning Through Self Assessment and Peer Assessment: Guidelines for Classroom Implementation. In Laveault D., Allal L. (eds). Assessment for Learning: Meeting the Challenge of Implementation. The Enabling Power of Assessment, vol 4, pp. 311-326. Springer International Publishing.

Purchase, H.C. (2000). Learning about interface through peer assessment. Assessment and Evaluation in Higher Education 25 (4): 341-352.

Reddy, Y. \& Andrade, H. (2010). A review of rubric use in higher education. Assessment \& Evaluation In Higher Education 35: 435- 448.

Rienecker, L. \& Bruun, J. (2012). Feedback. I Universitetspcedagogik, 459-480. København: Samfundslitteratur.

Tsai, C.-C., Lin, S.S.J. \& Yuan, S.-M. (2002). Developing science activities through a networked peer assessment system. Computers \& Education 38: 214-252.

Topping, K. J. (2009). Peer assessment. Theory into practice, 48(1), 20-27.

Vlachou, M. A. (2015). Does Assessment for Learning Work to Promote Student Learning? The England Paradigm. The Clearing House 88 (3): 101-107.

William, D. \& Leahy, S. (2015). Embedding Formative Assessment: Practical Techniques for K-12 Classrooms. West Palm Beach:Learning Sciences International.

Winsløw, C. (2006). Didaktiske Elementer: En indføring i matematikkens og naturfagenes didaktik. København: Biofolia.

Yorke, M. (2003). Formative assessment in higher education: Moves towards theory and the enhancement of pedagogic practice. HigherEducation45: 477-501.

Zoller, U. \& Ben-Chaim, D. (1998). Student Self-Assessment in HOCS Science Examinations: Is There a Problem? Science Education \& Technology 7: 135-147. 